\title{
THE FAILURE OF THE UNITED NATIONS ATOMIC ENERGY COMMISSION: AN INTERPRETATION
}

\author{
EDWARD SkTIS*
}

I

FTER nearly two years of work, the United Nations Atomic
Energy Commission has apparently brought its life to a close.
The tremendous responsibilities which were assigned to it have not been fulfilled. It has been impossible to achieve agreement between the Soviet Union and the United States; the Soviet Union has twice refused to accept the majority reports of December I946 and September I947, while the majority has just concluded after further study that the "Soviet proposals of June II, I947 . . do not provide an adequate basis for the effective international control of atomic energy and the elimination from national armaments of atomic weapons," and for this reason "no useful purpose can be served by further discussion of these proposals by the Working Committee." Without having been discharged by the Security Council, the Commission has discontinued its activity.

Why has this happened? Progress has certainly been made. The Second Report represented a definite advance in concreteness and specificity over the First Report. Both reports presented the outlines of a control scheme, the workability of which has never been contested by the Soviet Union. The Soviet proposals of June Ix, I947 were far more specific than the vague and contradictory statements of the Soviet delegates in the preceding year. The majority had approached its task with a very serious desire to construct a practicable scheme. And at the very end, Mr. Gromyko, who at the beginning of the year has warned against expecting anything much from the re-examination of his proposals of June II, I947, suggested that the Soviet Union would like to have the discussions continue. Yet the Atomic Energy Commission, its task still unfulfilled, has ended its activities.

The unwillingness of the majority to continue is the result of two years of exasperation, frustration, and the growing conviction that the Soviet Union does not want an effective international control scheme established. The debating tactics of the Soviet delegates and of the Polish and the Ukrainian delegates who supported them-general and abusive attacks,

* Reader in Sociology, London School of Economics; Committee on Social Thought, University of Chicago. 
evasiveness, unwillingness to reply specifically to specific questions, blandly maintained contradictions, constant reiteration of dogmatic generalities, and frequent refusal to elaborate on them-would have been trying enough and deleterious enough to a discussion which showed signs of moving toward substantive agreement. But no progress toward agreement was being made, and there were no visible signs that any could be made in the near future. Besides, the general deterioration of relations between the Soviet Union and the United States led to the conviction that even if an agreement could be achieved within the Commission on the control system itself, the mutual confidence required for its effective establishment and operation would be lacking.

\section{II}

The labor of nearly two years did bring forth certain definite intellectual achievements, and both sides made some progress in their thinking on the control problem. Neither side, however, made significant progress toward the position occupied by the other. An attempt to interpret the failure of the Commission will be aided by an examination of the obstacles involved in the substantive proposals themselves and in the attitudes in which they were enmeshed, which made progress so slow and agreement so unattainable. ${ }^{x}$

In the first place, the Soviet delegates came to the Commission almost totally unprepared, without any sort of thought-out program. They began with an immediate demand on the Americans to renounce their one advantage and bargaining instrument, and they offered nothing in return. The Americans, on the other hand, began their campaign with an elaborate program which contained at least two items which were rather alarming to the Soviets: I) the letting loose of an army of foreign inspectors and factory managers on Soviet territory and 2) the abolition of the veto power in the Security Council. In the present international political situation, the Soviets see the "iron curtain" against foreign observers as one of their most strategic defense weapons, while the veto power has been a great comfort and reassurance against the usually hostile majority in the Security Council.

The failure of the Soviet policy makers to study carefully even the Acheson-Lilienthal Report may be inferred from the fact that although Gromyko was able to discuss the veto-prohibition phase of the American proposals as early as June I9, I946, five days after it was presented, he

\footnotetext{
$x$ For a more fully developed exposition of the analysis presented in this section, see the author's The Atomic Bomb in World Politics (1948).
} 
was obviously not prepared to discuss the substantive American proposals at that time, although they resembled very closely the Acheson-Lilienthal proposals of several months before. The unpreparedness of the Soviet representative resulted in an optimistic attitude during the first month of the Commission's activities. Gromyko's opposition to the veto prohibition did not seem at that time to raise an insuperable obstacle to agreement. There were grounds for hope that the Americans could be brought to recognize that their demand for veto prohibition had more formal than substantive advantages and that they would renounce the more offensive parts of it in return for acceptance of the main elements of the proposed control structure. There was indeed in those early days a quite reasonable basis for expecting a compromise, since Gromyko had suggested that in addition to drafting the convention which was to outlaw the use of atomic weapons, the Committee which he recommended was to propose "measures to prohibit the production of weapons based on the use of atomic energy and to prevent the use of atomic weapons and all other main kinds of weapons capable of being used for mass destruction; ... measures, systems and organizations of control over the use of atomic energy and over the observance of the terms of the above-mentioned international convention for the outlawry of atomic weapons; . . the elaboration of a system of sanctions to be applied against the unlawful use of atomic energy."

This optimistic interpretation was rebuffed by Gromyko's next major contribution to the discussion on July 24, presumably after Moscow had had time to think over the American proposals. In addition to reiterating his arguments against the prohibition of the veto power, he said that "the United States proposals ... in their present form could not be accepted in any way by the Soviet Union, either as a whole or in separate parts." Moreoever, he asserted that where there were infringements on the prohibitory convention, they were to be punished by the states in which they occurred.

Meanwhile, the French, Dutch, and Australian delegates, foreseeing the snags certain to arise in connection with the veto discussion, tried to shift the discussion to a more technical level where the possibility of agreement seemed greater. The Americans did not lend themselves to this modest effort at conciliation, and Mr. Eberstadt's Third Memorandum, in which the limitations on the veto power were made even more explicit, kept the veto question in the center of attention at a moment when the creation of a conciliatory atmosphere was indispensable. The subtlety and ingenuity of Mr. Eberstadt's and Mr. Baruch's arguments did not assuage 
the Soviet delegate, and the main outlines of the first real breach between the two sides became set in a way from which they never varied during the ensuing discussions.

While the Soviet delegation participated in the unanimously adopted report which declared that international control along the lines set forth in the American proposals was technically feasible, the Soviet delegates (even the same persons) continued to act, in the other phases of the Commission's work, as if the only control would be national control. Thus on October 22, $\mathrm{r}_{946}$, in the course of a discussion of a world-wide inventory of uranium and thorium deposits, Mr. Alexandrov said that the Soviet Union could participate easily thanks to state ownership of mineral resources in his country. When other delegates asked whether the inventory was to be conducted by an international body, Mr. Gromyko, after some delay, replied: "The Soviet delegation considers the national control to be sufficient, and therefore it might be possible to extend the discussions on safeguards in the line of national controls." ${ }^{2}$

Thus far the gap seemed as wide as possible, the Soviet and American positions being at opposite poles on the questions of the veto power, sanctions, the character of the control agency, and the timing of the destruction of existing stockpiles of atomic bombs. Virtually the only point of agreement was that no state should possess or produce atomic bombs.

On October 28, I946 Mr. Stalin said in an interview with Hugh Baillie that "a strong international control is needed." A day later in New York at the General Assembly, Mr. Molotov began an intemperate onslaught on American foreign policy which ended with Soviet reaffirmation of the necessity of effective control over atomic energy.

The opportunity for a new beginning was thus presented. Unfortunately the American delegation suspected a dangerous possibility in the Disarmament Resolution. It was apprehensive lest the Soviet connect the discussion of disarmament in conventional weapons with that in atomic weapons in a way which would greatly delay the establishment of an ef-

${ }^{2}$ Various American scientists, beginning with the Chicago group, have proposed a moratorium on the large-scale development of atomic energy for peaceful purposes as a means of avoiding the thus far insoluble problem of control where large-scale development is permitted. Although it is true that there would be no problem of guarding against diversion if there were no large-scale operations, a large international inspection staff conducting freely ranging aerial surveys and surveillance of mining activities would still be necessary. (If that were not allowed, then it would become necessary to have a staff of inspectors roaming freely throughout the industrial installations of each country.) Since one of the elements in the breakdown of negotiations was Soviet refusal to agree to a world mineral resources survey by an international body, it hardly seems to be likely that they would agree to a measure which might also appear to them to be directed toward hampering their free development of their own economy while it gave other countries opportunities for espionage in the Soviet Union. 
fective control system, and it also feared that the proposed Census of Armaments would engulf the American atomic bomb stockpile. The new Soviet maneuver which aimed to reopen the path to agreement really injured the chances for agreement by threatening simultaneously to weaken America's bargaining position while removing that for which it sought to bargain further into the future. To avert this danger Mr. Baruch began to press for a speedy report by the Commission to the Security Council, and despite strong Soviet resistance, he obtained it. While the rest of the majority of the Commission was willing, although not entirely happy, to accept Mr. Baruch's deadline, December 3I, 1946, for the completion of the First Report, they were considerably less than happy about Mr. Baruch's adamant attitude on the veto. General McNaughton urged caution in the discussion of the veto:

If there came about a situation where it was felt that [military] sanctions would have to be applied against one of the Great Powers, it would be a condition of absolute war, whether the opposition of the one power took the form of resistance or took the form of veto. The only way in which it could be overcome would be by the use of force, and the use of force against a great power means war. From what I have said about sanctions, it will be evident, I think, that we must be careful in the phrasing of this Report.

Other delegates also expressed their wish for a more conciliatory American attitude and the sentiment of many of the delegates who ultimately supported the American position was spoken by the Chinese delegate, $\mathrm{Mr}$. Quo, who said: "In principle, if it comes to a vote, we will vote for the Baruch resolutions, but . . . it may be desirable to have a unanimous decision by our commission."

Mr. Baruch ingeniously attempted to win Soviet acceptance of his demand for the prohibition on the veto by distinguishing between foreseeable and specifiable infringements on which unanimous agreement could be achieved in advance and for the punishment of which there should be no veto, and those infringements which could not be clearly defined in advance, sanctions for which should remain in the hands of the Security Council with its usual veto power. The French and Canadian delegates were not impressed with this distinction. Even the cautious Sir Alexander Cadogan, who seldom raised objections to the American viewpoint, said on December 30 that he himself "had ... wondered whether a critical passage of the report dealing with this point might have been otherwise worded and had hoped that, somewhat differently stated, it might at that stage even have commanded unanimous acceptance."

Mr. Gromyko's rebuttal combined the usual Soviet desire to delay a decision by requesting an item-by-item consideration of the American 
proposals, which had already been discussed in great detail, "in order to include absolutely necessary corrections," with a contradictory and comprehensive rejection of the Report as a whole. In the course of this attack, Gromyko went further toward a vetoless international control scheme than at any previous moment when he agreed that "it is indisputable that control organs and organs of inspection should carry out their control and inspection functions acting on the basis of their own rules, which should provide for the adoption of decisions by a majority in appropriate cases."

Although it had become more definite in its renewed commitment to international control, the Soviet policy had thus far never made any proposals more specific than the generalities about the necessities and virtues of a prohibitory convention. On February I8, I947, however, Mr. Gromyko submitted twelve amendments to the Report, one of which was a clearly implied acceptance of "international management." It was a demand that "inspection, supervision and management on the part of an international organ shall be applied with regard to all existing plants for the production of ultimate atomic minerals immediately after entry into force of an appropriate convention or conventions." Similarly the other references to management in the Report were allowed to stand. The veto prohibition was, of course, deleted by an amendment. For nearly two weeks the signs of rapprochement seemed most promising. But on March 5 , instructions having presumably arrived from Moscow, an unprecedentedly vehement attack on the American scheme was launched. "Management" was now designated as "thoroughly vicious and unacceptable," representing an attempt at American capitalistic domination of the economic life of the Soviet Union. Mr. Gromyko still adhered, however, to "effective inspection [as] . . a necessary component part of the system of international control."

Ten days later he submitted an amendment to the amendment which had called for the establishment of management by the international agency over the existing American plants. His superiors in Moscow were gradually beginning to clarify themselves and to make up their minds. They had decided against management almost a year after it had first been authoritatively discussed in public. But although they also had decided in favor of inspection, they had either not worked out their views sufficiently or else had not communicated them to New York. In any case, when the Soviet delegate was asked in connection with his amendments whether inspection would allow a search for clandestine plants, he delayed answering by saying that the scope of inspection would have to be defined in the convention. Similarly he evaded discussion as to whether the in- 
spection personnel would be international in composition by saying it would be "under international authority." When pressed further he agreed to accept a written question on the matter, expecting apparently that in the meantime new instructions would come from Moscow. Apparently they did not come since when the question was submitted four days later, he asserted that it was out of order because it led away from the discussion of the Soviet amendments!

Finally, on June II, I947, the Soviet Union presented its own proposals. They were proposals for inspection of the type which had been rejected as insufficient by the Acheson-Lilienthal Report. They were accompanied by no supporting arguments which demonstrated either their own adequacy or the superfluity of a system of control such as was presented in the First Report. Mr. Gromyko now insisted that work in the Control Committee be discontinued and that the Soviet proposals be considered in lieu thereof. He did not succeed in this; meanwhile the Soviet delegate in the Control Committee, while refusing to participate in the substantive discussions, continued throughout June and July to protest about the waste of time involved in talking about the "internationalization of the atomic industry." Yet, as the group working on survey problems was about to conclude its deliberations, the Soviet delegate insisted that more time be spent on the question.

When the Working Papers were completed by the Control Committee, Mr. Gromyko attacked them as being based on the original American proposals and therefore constituting no basis whatsoever for solving the problems raised. At the same time he continued to press for the detailed consideration of his June II proposals, which other members of the Control Committee felt had already been discussed in other forms, and which did not provide, according to a Canadian resolution, "an adequate basis for the development by the Committee of specific proposals for an effective system of international control of atomic energy."

At this point, Mr. Gromyko changed his line somewhat and began to argue for consideration of the points-the existence of which he had just recently denied-on which there was fundamental agreement between the Working Papers and his own proposals. He also expressed a tentative approval of, or at least interest in, the quota system (for the geographical apportionment of atomic energy activities) which had been set forth in the Working Papers.

The majority, probably exasperated with Gromyko's about-face reversals, his generalities, and his crude attacks, disregarded his request, which might if seriously undertaken by both sides have offered some pos- 
sibility of a more favorable development toward compromise. Whatever the causes, it was one of those evanescent opportunities which the Commission should have accepted despite the probability that it might turn out to be another mare's nest. Instead the majority adopted the Canadian resolution quoted above. On the same day (August II) Sir Alexander Cadogan transmitted a series of questions to Mr. Gromyko and on September 5 the answers were delivered. They repeated with insistence his old point about the need for a plurality of conventions, the first of which must be one prohibiting atomic weapons. As to whether his reference to "periodic inspection" excluded the possibility of "continuous inspection," Mr. Gromyko was evasive, saying only that periodic inspection did not mean inspection at fixed regular intervals. (The meaning of "periodic inspection" remained open until the very end, even though Mr. Gromyko did reject, in the I948 discussions, "continuous inspection" which he claimed would be equivalent to "management.") The fourth British question referred to "special investigations" in cases where there was a suspicion of violation, inquiring into the grounds on which such investigations could be initiated. Gromyko replied that special investigations could be carried out where reports submitted by governments seemed to raise suspicions, where the international control commission discovered discrepancies between their checking of national accounting data and their observations of nuclear fuel available, or where their inspectors reported suspicious activities. Inasmuch as the Soviet proposals provided that the inspectors "normally . . . will visit only declared plants," it is difficult to see how they could legitimately have their suspicion aroused. Furthermore because of the indeterminacy of the "material balance" in extraction and separation processes, congruity between "nuclear fuel available and accounting data" would not be a safeguard against diversion. In reference to control activities other than inspection, the Soviet position was that "supervision, management and licensing do not follow from the tasks of the establishment of strict and effective international control." The control procedures which the Soviet reply enumerated included: $I$ ) inspection and investigation, 2) accounting, 3) working out and assignment by the Commission of rules of technological control of the plants, 4) requesting from governments information relating to the activities of plants of atomic energy, 5) submitting recommendations to the Security Council. (It should be noted as an instance of the slipshod and stumbling procedure of Soviet policy-making, even on the highest levels, that control by quota assignment, which Gromyko had mentioned sympathetically nearly a month before, was not listed among the control techniques.) 
The Soviet replies did nothing to bridge the gap between the June II proposals and the Working Papers which the Working Committee had summarized on August I5 as bearing on: $x$ ) veto on sanctions, 2) safeguards for strict international control, 3 ) the number of treaties or covenants (the majority had wanted only one inclusive treaty while the Soviets wanted one for prohibition of atomic bombs and possibly another for control), 4) the sequence and timing of stages, 5) research by the international agency on atomic weapons (which the majority had sought to reserve to the international authority and which the Soviets had sought to ban entirely).

The Working Committee omitted one very important difference between the Americans and the Soviets with regard to the destruction of bombs. Whereas the Soviets had sought from the very first the destruction of the American atomic bomb stockpile, they never specified whether by destruction they meant detonation or separation of casing and mechanism from fissionable material and destruction of the former. The significance of this issue lay in its indication of a) the failure of the Soviet policy makers to think through what was really involved in their demands and b) the increasing unwillingness of the Americans to meet the Soviet demands as long as no concessions were forthcoming from the Soviet side.

Nonetheless, despite the fact that the Americans and, to an increasing extent, the rest of the majority showed little inclination as the discussion continued to make concessions, the Second Report and the Working Papers on which it is based were conciliatory in restricting the range of aerial surveys and inspections for suspected clandestine activities. These represented the most considerable effort of the majority to take Soviet sensibilities and obduracies into account and to offer as many safeguards from unnecessary intrusion as were compatible with effectiveness.

Mr. Gromyko attacked the Second Report as "absolutely unsound," although he once more flirted with the quota scheme. He produced neither arguments in favor of the effectiveness of his own June II proposals nor arguments against the superfluity of the devices recommended in the Reports. He simply charged the latter with being "unsound from the point of view of the organization and technique of international control; contrary to the very idea of international control; the idea of an international organ owning atomic energy plants and atomic raw material precludes in point of fact international control as such."

Although the majority must have had very little hope of substantial accomplishment through further discussion in the Commission, it was decided on December 19, after several months of suspension, to reopen the 
examination of the Soviet proposals. The re-examination ended where it began-there was agreement only on two general principles: I) there should be some type of international control by an agency using international personnel and 2) sovereign states should not produce or possess atomic bombs. On the former, there was unbridged disagreement concerning the type of control: The Soviets wished to allow only periodic inspection and special investigations, the majority wanting management of all "dangerous" activities. On the latter issue there were marked differences on timing: The Soviets wished a convention to be concluded immediately for the destruction within ninety days of all atomic bombs, and they refused to make it contingent on the conclusion of a control convention or treaty. (Typical of Gromyko's contradictory approval is that after being more explicit on this point than he had ever been before, in his last remarks he seemed to complain that no one had ever made a proposal to make the conclusion of a prohibitory convention dependent on the conclusion of a control convention.) The majority looked forward to a time when, as the control system was being established, the bombs would be "disposed of."

The Americans and their majority associates never made any attempt to work out in the Commission a telescoped timing scheme which would give the Americans the assurance that while they were renouncing their atomic bombs the other countries would be under control and which would simultaneously reduce Soviet anxiety during the period when control would prevent them from making atomic bombs while the Americans still retained theirs. This was a serious omission by the Americans. Even if such a scheme had proved unacceptable to the Soviet Union, we would at least know that we had done all that was in our power to obtain agreement.

The disagreement on the veto and sanctions was actually one which could have been eliminated by a more conciliatory American attitude. Not only was its timing bad, but it was unimportant in the light of principle and wrong in the light of expediency. Assuming that an existing international control system afforded adequate "danger signals," the detection of violations, if they were of sufficient magnitude, would result in vigorous actions of self-defense (probably war) by the states which regarded themselves as endangered by the violator. On the other hand, even if the Security Council needed only a majority instead of unanimity to invoke sanctions against a violator, if the violator were strong enough and also refused to desist, then there would be war also, this time under United Nations auspices-an advantage it is true, but a meager one. Nor does the 
contention of the proponents of the abolition of the veto on sanctions that preventive action would be automatic if there were no veto in the Security Council carry much weight. There would always be the possibility of "deals" among the members of the Council and "independents" might well exist whose indecision would be the objects of the cajolery and threats of the violators and of those who wished for instantaneous and severe sanctions.

Even though a concession on the veto question might not have changed the Soviet refusal to allow an effective control scheme, still it was a concession which we should have made in order to be sure that we left no opportunities for agreement on the effective minimum unexplored. The fact that we did not do so is evidence of our rigidity, obstinate pride, and failure to think through what was involved in the discussions. And since the Soviets argued so frequently from the precedent of the alleged effectiveness of the prohibition on the use of poison gas in the past war-a prohibition which allowed research, development, and stockpiling to go on-we might have proposed a similar convention as a token of our good will. We would have then been in a better position to turn down the Soviet version of a prohibitory convention independent of the conclusion of a control convention; but we did nothing of the sort.

The rigidity was thus by no means entirely on the Soviet side. We understood better what was involved; we had more information, more free and intelligent discussion than the Soviets; we began with more good will but not with enough. Since we can never be sure that some of the concessions of the type mentioned above might not have been helpful in reducing the range of disagreement, we cannot attribute all responsibility for the failure of the discussions in the Commission to the Soviet Union or to the general international situation. Some of it also rests with us.

\section{III}

Did the Soviet Union wish to have the atomic bomb subjected to international control? That question cannot be answered as a whole. The Soviets certainly wished to see atomic bombs eliminated from national armaments at present, i.e., as long as only the United States possessed them. In view of their fear and suspicion of the Western countries, they could hardly have believed that the inspection scheme which they finally put forward could be effective. It seems even more probable that the Soviet Union did not begin the negotiations in the Commission with the definite determination to establish a system of international control.

Why did the Soviet Union not wish to have the atomic bomb subjected 
to effective international control? I should like to emphasize here their lack of understanding of the political and military implications of the bomb and the relationship of this lack of understanding to some of the characteristics of the Soviet élite.

The Soviet élite is a revolutionary élite with a state of mind which sets it in conflict with the rest of its society and with all other societies, an élite still motivated by universal hostility and distrust. For both rational and irrational reasons, the Soviet élite fears the dissatisfaction of its citizenry. The irrational reasons are derived from the general state of psychological insecurity of a revolutionary élite of which there are still many survivors among the members of the Politburo. The rational reasons stem from their apprehension that dissatisfaction with the low Soviet standard of living as compared with that of the West might be expressed by the Russian people in a revolutionary way. Distrustful toward their own people to the extent of forbidding them to discuss and criticize freely basic alternatives of policy, they therefore doubly suspect anything which would bring foreigners into the Soviet Union to peer about with some independence and to carry out of the country whatever information is gained. And the mere presence of those foreigners on Soviet soil might possibly enable their own citizens to acquire conceptions of life in other countries quite different from those which are officially imposed.

At present and for many years, as we know, the rulers of the Soviet Union have tried to make their people believe that anything that goes on in the Soviet Union is better than anything that goes on elsewhere. The war endangered the Soviet pattern of preventing their people from knowing the nature of life in the outside world-Russian soldiers were in foreign countries by the millions. To forestall the anticipated difficulties, the Soviet élite has been conducting in all spheres of life an extremely energetic anti-Western campaign. It is probably not so much the actual danger, as the fear of danger, arising from unrest which prompts the Soviet élite to be uneasy about an international control scheme.

But the entire Soviet fear of international control cannot be explained by reference to rational and irrational xenophobia and the psychological insecurity of the Soviet ruling group. These fears, which are reinforced by traditional Marxist-Leninist dogmas about imperialistic designs against the Soviet Union, and the conventional secrecy preoccupations of military bureaucrats have been one factor in the delaying tactics of the Soviet delegates in the Commission. These tactics indicate a Soviet desire to prevent the Commission from reaching the conclusion which it actually dida conclusion which would place the Soviets in a somewhat unfavorable 
light-since even many Communist sympathizers could not resist the temptation to be impressed by some elements in the original American proposals and were hard put to explain away their rejection by the Soviets. It was, therefore, simply undesirable from the standpoint of the Soviet propaganda for the proceedings to conclude too early.

But a considerable part of the Soviets' delaying tactics are to be accounted for by their ignorance of the nature of the atomic bomb and their uncertainty as to its significance. The frequent repetitions and evasions of the Russian delegates in the face of questions from the other members of the Commission are to a great extent the result of the failure of the instructions from Moscow to take into account the possibility that certain kinds of questions would be raised. The inadequacy of these instructions and the delegates' frequent fluctuation in attitude indicate that their superiors in Moscow were simply unable to make up their minds in a consistent and comprehensive way. The inconsistency and narrowness of the instructions point to the superiors' uncertainty about the nature and implications of the bomb. They were placed in the unfortunate position of being simultaneously unable to accept a device as repellent as international control and uncertain as to the degree to which their security might be jeopardized by rejection of such control. Their delaying tactics permitted them to delay coming to grips with the dilemma in the hope that something would turn up (e.g., their own development of the bomb or discovery that the bomb is not really as terrifying as the Americans claim) enabling them to dispense with the necessity for accepting international control.

Given their desire to remain at peace with the United States, which we accept as axiomatic, it seems that only ignorance of the bomb's potentialities and the failure to reflect on the nature of an atomic armaments race could allow them actually to obstruct, as they have, the establishment of the scheme which could have helped to prevent an atomic armaments race and an atomic bomb war which would be generated by a situation in which several large states already hostile toward one another possess atomic bombs.

How may we account for this lack of awareness of the military and political significance of the bomb-an ignorance which, when coupled with their distrust of foreign cultures and their uncertainty, allows them to resort to cavalier tactics which can only injure themselves as well as the rest of civilized mankind?

The initial factor is Soviet national pride. The first atomic bombs were detonated when Soviet national pride and suffering were at their height. 
The suffering was made bearable in part by their sense of achievement in the war and by the belief that their rulers were superior to all others in ingenuity, wisdom, and strength. Acknowledgement of the importance of bourgeois technical and scientific achievement in which they had had no share, even if they could bring themselves to admit it, might have appeared to the Soviet leaders as too injurious to the self-esteem of their people and thereby injurious to their own power position. It should also be remembered that claims for the potency of the atomic bomb were made with greatest vigor after the end of the Japanese war when the needs of Soviet self-esteem demanded that victory in the Japanese war be credited to Soviet arms. The claims about the atomic bomb were rivals to this demand, and in their need to bolster their own and their people's morale, the Soviet élite could not accept them.

Furthermore, most of what the Soviet leaders knew about the power of the bomb was learned from the American privately owned press, the deliberate mandacity of which is a basic article of the Marxist-Leninist doctrine. Much later at Bikini they were able to learn of it directly, but under American auspices, which did not overcome the suspicion that the whole thing was a hoax. Information developed by the routine business of espionage, for example in Canada, was apparently treated in a correspondingly routine fashion by Soviet intelligence officers and probably did not penetrate very far upward to the level where its significance might possibly have been more accurately and realistically assessed. ${ }^{3}$

It is also quite possible that the energy with which the United States demanded a drastic system of international control also led the Soviets to underestimate the bomb. The Soviets' conception of international relations and especially their conception of the motives of bourgeois statesmen do not prompt them to expect acts of generosity or of the renunciation of power on the part of their "natural enemies." If the bomb were really as powerful as the Americans declared it to be, would they be as willing to give it up as they claim to be? To this question a plausible answer would be: The bomb is not so powerful but by making it appear to be so, the Americans hope to force us to enter into a scheme whereby their agents will enter our country, learn all about our resources and weaknesses, and thus prepare themselves more adequately to do battle against us.

Once the disposition to disbelieve the reports of the atomic bomb's destructiveness had taken root in the minds of the Soviet elite, it was rein-

\footnotetext{
3 Stalin's indifference to Truman's announcement of the bomb at Potsdam, as reported by Byrnes and other participants, is certainly compatible with the hypothesis presented here concerning the Soviet elite's unawareness of the significance of the bomb at least in I945 and 1946.
} 
forced by the Soviet system of diplomatic representation and of the acquisition and transmission of intelligence. Soviet diplomats are granted no discretionary powers in negotiations and their briefing tends to be narrow and specific. The narrowness of their instructions and the omission of their superiors to provide them with alternatives give the Soviet diplomats little opportunity for wide ranging discussion, for exploration, and for the acquisition of insight into the minds of their opposite numbers. There is a marked tendency among subordinates everywhere to tell their superiors what they think their superiors wish to hear. This is probably very much the case among Soviet diplomatic representatives, who must always be alert to avoid an independence of judgment which might be interpreted as a sacrilegious and personally dangerous "deviation." In consequence their reports to their superiors can scarcely be expected to be very revealing. The Soviet élite is thus insulated from a realistic understanding of the way in which the bourgeois world works.

For all these reasons, the Soviet élite has irresponsibly treated the atomic bomb as a relatively minor matter. It thus has a very large share in the heavy guilt which has been incurred by allowing the present crisis in international relations to develop.

\section{IV}

It is reasonable to believe that when the Commission's discussion began, the State Department, the White House, and most of the politically interested sections of the American people were in favor of effective and comprehensive international control. They might not have liked it if they actually obtained it and they might have even withdrawn from it once they perceived in practice what it involved, but when the Commission discussions began they were definitely in favor of it. The American people, thanks to the exertions of the atomic scientists, knew more about the destructive potentialities of the atomic bomb than other people. Their lives were less distracted by immediate physical deprivations, and they could devote more attention to the discussion of wider issues and the remoter future. It might well be that their motives for supporting international control did not arise simply from a disinterested concern about the future of civilization-but rather from fear of what might happen to themselves.

Physical and social scientists began very early, independently of the government, to think about international control arrangements. The Acheson-Lilienthal Report represented a high point in the evolution of American thinking on the problems and, by the time the American delegation to the Atomic Energy Commission was appointed, a great deal of 
imaginative and sophisticated thought had been invested in the subject. Unlike the Soviet delegation, the American delegation was provided with a rich background of inventive exploration into alternative possibilities.

The differences in point of departure may be attributed not only to the greater knowledge of the American public about the bomb, which is partly a function of the freedom of agitation and discussion within which the American scientists and politicians could operate, but also to the fact that the freedom to discuss public policy alternatives prior to or concurrently with the government's own deliberations enabled the American delegates to understand the strong points of their proposals since they had been able to discuss and analyze numerous alternatives. The availability of the experience of the scientists who had worked on the Manhattan project was certainly a great advantage but probably equally important was the prior initiative of the Yale, Chicago, and Carnegie groups in attempting to formulate the problems of international control. The Soviet procedure, in which all discussion of alternatives is confined to the government, meant that their policy makers did not have before them such a wide range of possibilities, and consequently their choice could not be defended with the same degree of relevance and substantiality as the American proposals.

The American support for the abolition of the veto power on sanctions for infringements on a control agreement rested on different foundations. Many Americans accepted Mr. Baruch's own addition to the AchesonLilienthal scheme as an important improvement on United Nations procedure. The high hopes of the majority of the American people in the United Nations had already begun to sink into disillusionment and chagrin in the face of repeated Soviet use of the veto power in the Security Council. Mr. Baruch's proposal was therefore greeted as a means of making Security Council decisions effective-as well as of making the international atomic energy control authority effective in the performance of its tasks.

Publicly available evidence does not reveal how unanimous the government was in the anti-veto attitude. While Mr. Baruch and his American associates argued emphatically for it in the Commission, the American delegates in the General Assembly in the autumn of 1946 did not stress the necessity of eliminating the veto power. A plausible hypothesis is that Mr. Baruch, having been commissioned to work out the American proposals, included the veto prohibition as coming within the range of his allotted discretion. Not only would it meet a need to give an individual stamp to a body of proposals largely taken over from the Acheson-Lilien- 
thal scheme, but it would also enable him to gain from the Soviet Union a very great concession in return for what the United States regarded (from its side) as a very great renunciation-namely, the renunciation of the atomic bomb. His success in obtaining this concession from the Soviet Union would have been of great aid in facilitating the ratification of a control treaty by the Senate. In the course of the debates, as the delaying obstructive tactics of the Soviets became more apparent, the veto prohibition, which became even earlier a major stumbling block in the negotiations, acquired the additional function of a stick with which to beat the Soviets before American and Western European public opinion. The fact that the United States did not even make any attempt at a compromise on the veto question may be attributed to personal involvement in the proposal on the part of the American delegates and the expectation, as the hope of agreement diminished, of exhibiting the Soviets as the villains of the piece before a public which had already taken sides on the issue.

It seems also likely that as the expectation of agreement declined almost to nothingness and as exasperation with the Soviet delegates grew within the Commission, the American striving to have the majority control scheme realized also declined, being replaced by the routine elaboration of implications and the exploitation of a morally advantageous position for propaganda purposes. The establishment of an effective control scheme ceased to be the central issue of the discussions.

We have already described the relative inflexibility of the American attitude during the negotiations and remarked on the unconciliatory attitude-even where as in the days prior to the acceptance of the First Report close friends of the American viewpoint earnestly sought some concessions. Mr. Wallace's furious attack on Mr. Baruch in September I946, which sought to minimize the veto question by an interpretation which Mr. Evatt presented later in the Commission, and which, contrary to Mr. Wallace's assumption, the Soviets would not accept, undoubtedly helped to make the American attitude more rigid. To have accepted Mr. Wallace's line after his attack, would have been too humiliating to those whom he had attacked.

There was a chance for a modification of the American attitude on the veto after Mr. Baruch's rather stern resignation at the end of $x 946$, but the Soviet onslaught on the American proposals in February and March I947 made this more difficult. By this time, the general situation had deteriorated to such an extent that only the best possible human atmosphere in the Commission's meetings could have maintained optimism about a successful outcome. But on the contrary, acrimony between the majority 
and the minority became too strong despite valiant efforts by the French delegates in particular to ameliorate the situation. At present the situation is so unpromising as far as atomic energy control as such is concerned that even if the Soviets were to accept the majority plan, the American people and their leaders might indeed be too distrustful of the Soviets to accept their scheme which they themselves had proposed. The international control of atomic energy has ceased for most people in the United States to be a relevant alternative policy in the present situation.

Despite the advantages of information and discussion, the American government and people have allowed the drift of events, their irritation and dismay over the fear-impelled obstructiveness, the dogmatic obstinacy and aggressiveness of the Soviet Union, and their own self-righteousness to drive them into a situation in which a policy is gradually taking shape from which insight into the nature of the atomic bomb is excluded. It is true that purely military calculations are slowly and uncoordinatedly coming to take atomic bombs into account, but diplomatic and strategic calculations are being made as if the atomic bomb were "simply another bomb." The people, press, and government of the United States have come to the point where they regard an atomic bomb war as something which, however horrible, must be reckoned with as a datum. As long as the threat of such a war is not imminent, they view the possibility with uneasy equanimity. In so far as they hope to avoid that war, they rely on procedures which were appropriate and tolerable in a world of numerous states of more or less.equal power and weapons of equal and limited destructive potentialities.

Having disarmed so rapidly in most categories-except for the atomic bomb, and to such an extent as to cause a serious imbalance of military power in the major power-vacuum of Western Europe, the United States has now thrown itself into a near panic in its contemplation of the results of its poorly thought-out policy. Trying now to redress the balance by bringing its armed forces up to moderate strength, the necessities of democratic politics have precipitated both in Europe and in the' United States a serious state of anxiety about the danger of war. The American policy, which begins to emerge, aims to fill the power vacua around the periphery of the area allotted to the Soviet Union at Yalta by economic stabilization and military reinforcement. The economic stabilization of Western Europe is a great and large-visioned measure which has, however, been placed in a unfortunate context; it has been associated with a policy 
which justifies the economic measures in terms of negative anti-Soviet consequences-consequences which by their unforeseen repercussions might negate the beneficial aspects of the policy.

The present American policy is not based on the expectation of an immediate Soviet expansion into Western Europe by military means-and in any case American policy is not oriented toward the immediate military prevention of such an expansive movement. But despite the expectation that the Soviet army will not move westward at present, the United States government in so far as it has any clear ideas on the matter at all, seems to think that in about two or three years or sometimes later, the danger of such an expansion will be greater-at a time when America will have been armed to a point where its non-atomic armament will be more or less comparable to the Soviet Union, and its atomic armament undoubtedly far greater. This greater danger is what American policy then expects to "contain" by its greatly expanded military power, assuming the correctness of American predictions that a) Soviet Union will not occupy Western Europe in the very near future. (If this expectation were not widely held in American governmental circles, there would be no sense in the Marshall plan. Especially in the more anti-Soviet interpretation of it, it would be inconceivable that the United States should give funds to a Soviet-controlled France, Italy, etc.) b) In the next three years when the Soviet motivation to invade the West might be greater, the increased armed power of the United States and the internal economic and political stability of those countries will provide a counter-incentive to the Soviet élite. Thus it is expected that peace will be maintained during the period and until the time that the Soviet Union succeeds in developing atomic bombs in quantity. If American policy is proclaimed as anti-Soviet containment and if generous economic rehabilitation measures are justified only on that basis, then it may surely be expected that the Soviet elite, with its fundamentally irrational hostility toward the outer world overlaid by its Marxist and Leninist doctrinairism, will arm with all possible speed, build atomic bombs, etc., to the limit of its capacity and strive to fill every power vacuum around its periphery as soon as possible. Even if we succeed in Western Europe-a task difficult enough in itself, there will still remain the Far and Middle East power vacua which are more intractable to our devices and in which Soviet jockeying for position will be interpreted as expansionism which will be in turn countered by our own attempts to redress the balance--and which by a cumulative process will raise the tension level between the two great states.

Thus in the case of American policy, too, just as in the case of Soviet 
policy, we can perceive a policy in which the atomic bomb is not taken centrally into account. It is more difficult to explain why American governmental and public leaders have allowed themselves to deal so incoherently with the atomic bomb. Conceivably the division of labor in the State Department, the political and psychological unimaginativeness of the professional military men, the irresponsibility of some of the White House advisors, the Soviet vetoes in the Security Council, the Soviet satellite policy, the breakdown of joint control in Germany, and finally the exasperation and hopelessness engendered by the nature of Soviet behavior in the Atomic Energy Commission account for this distraction of the mind's eye from the proper object of attention. Anti-Communism, a feeling of unappreciated generosity, and many other factors enter into this present tangle of anti-Soviet hostility in the United States. Their chief result is that in order to head off a danger which does not exist at present, certain lines of action are being followed which in their turn have a good chance to precipitate the war which we want so much to avoid.

\section{VI}

In the present international situation it was wise to discontinue the activities of the Commission. The reasons which motivated the suspension of the work of the Control and Working Committees must necessarily continue to operate as long as the level of tension between the United States and the Soviet Union continues to be high. When the Security Council meets to consider the Third Report, the United States delegate should offer to participate in an agreement to abstain from the use of atomic weapons, and it should also withdraw its demand for the prohibition of the veto on sanctions. These are now minor concessions but they should be offered even though the hope of stimulating a compromise attitude in the Soviet policy makers and delegates by these means is extremely slight. In any case, it would not be helpful for the Commission to go on with the elaboration of the details of the majority control scheme as long as the Soviet Union shows no signs of agreeing to its main principles. It would moreover only add to the already disastrously large sense of futility and irritation of disappointed hopes and expectations of further deterioration if the discussions were to continue in their recent vein. The prestige and possibilities of the United Nations would be further damaged by the continuation of such occurrences.

It has at times in the past year been recommended that the heads of the United States, the Soviet Union, and Great Britain meet to discuss and settle the atomic energy issue. It is certainly true that the Soviet poli- 
cy can only be changed by a direct decision of those at the top and that the information and recommendations necessary to the changing of the policy are most unlikely, given the nature of Soviet diplomatic procedures and organization, to come from the Soviet representatives in the Commission. It is, however, scarcely conceivable that under present conditions a conference among these three personalities could have any chance of success. The atomic energy issue is too intricately related to a wide complex of other issues, especially that of disarmament, the settlement of which by means of a conference in the present atmosphere seems improbable, to say the least. Such a conference would undoubtedly raise hopes too high; its probable failure would make it appear as if the last desperate efforts having failed, there is nothing else to do but to await and prepare for a war.

Before conferences can become effective, other means of stabilizing peace and mutual trust must be built up. This can be done not through conferences in which only promises can be made, but through concrete policies and achievements over a prolonged period. But as time passes, mining and processing carried on by sovereign states outside any international control scheme will reduce the degree of assurance with which any scheme to be established in the future can be accepted. There then can never be any certainty that all that has been mined and processed has been turned over to the international authority and this type of uncertainty will itself be an incentive to clandestine operations. Hence as the chances of the effectiveness of a control scheme to breed mutual confidence decline, the need for the creation of mutual confidence by other methods becomes more imperative.

Present day American policy-in so far as it aims only at the containment of Soviet expansion as its final goal-can never help to build this mutual confidence or moral consensus which is the only basis for the prevention of an atomic armaments race and an atomic bomb war.

American policy does, however, contain very important elements which can, if extended and placed in a different context, contribute greatly to the growth of political stability and moral consensus in the world. The extension of some form or other of the ERP to the Soviet Union, without irrelevant strings attached to its extension or, indeed, even the demand in the early phases for the further articulation of the European and Soviet economies is among the measures which might contribute to this. These measures will be costly and certainly difficult to encompass politically, and since they will also have to be accompanied by a stern opposition to any appeasement tendency which would allow further Soviet ex- 
pansion, should that be contemplated, will require great skill on the part of our governmental and public leaders. To combine firmness, that is, opposition to appeasement, the development of the power to oppose it and the simultaneous avoidance of loose talk and saber-rattling with generosity and patience greater than we have ever shown before will place demands on the American people which will be extraordinarily difficult to fulfil. But these are the demands which must be met if effective control of the atomic bomb is to be established and if the period of armed truce is not to be succeeded by an atomic bomb war. 